\title{
The Economic Feasibility of New Urbanist Development Strategies:
}

\author{
Case Studies from Regional Investigations
}

\author{
JOHN W. HILL \\ University of Maryland \\ USA
}

\section{INTRODUCTION}

This paper examines the comparative economic returns of ex-urban conventional and "new urbanist" development strategies. It is based on the analysis of seven hypothetical case studies designed by the author, reflecting site conditions, costs and constraints characteristic of the Middle Atlantic region.

Initial work leading to this paper was carried on in graduate research courses at the University of Maryland in 1993 and 1994. In the first phase, we examined the urban design "rules" which characterize traditional settlement patterns in our region, and suggested the benefits which would accrue from adopting these "rules" as a basis for a regional rural growth management policy based on village and hamlet zoning. The findings and recommendations of this work were published in the fall of 1994 by the Maryland Office of Planning. ${ }^{\prime}$

In the second phase, we weighed the economic feasibility of village and hamlet development strategies against conventional large-lot development strategies. The work tended

to demonstrate the economic feasibility of "new urbanist" strategies, but a lack of comparability in the case studies limited the work's value. In an effort to improve comparability, the author designed and analyzed the more consistent case studies reported here.

The paper begins with a comparison of conventional and "new urbanist" development strategies, goes on to argue the visual-environmental merits of the latter, and concludes with an economic comparison of examples of the two approaches.

\section{CONVENTIONAL LARGE-LOT AND CLUSTER ZONING}

Figure 1 illustrates the ubiquitous pattern of ex-urban development in the Middle Atlantic region. Motivated by market opportunity and permitted by regulation, this pattern typically consists of scattered, large-lot development projects on culde-sacs accessed from rural arterials. Lot size varies, but in many counties in our region basic residential zoning law permits rural development at five acres per dwelling unit. On a given parcel, a developer may also be given the option of

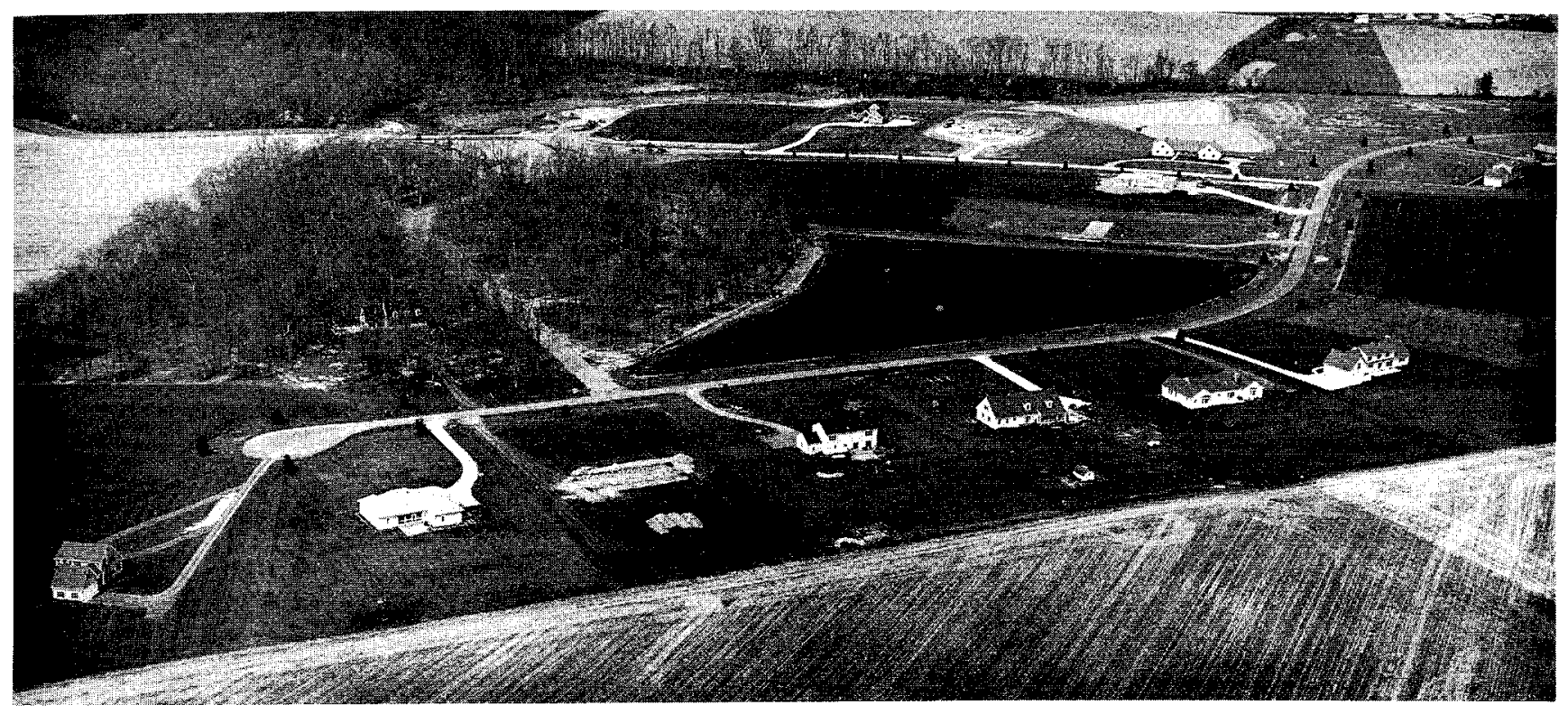

Fig. 1. Conventional large lot development 
"clustering" a development on smaller lots, providing the overall five-acre density is maintained. For example, in Calvert County, the northern part of which has been developed as bedroom suburbs of commuters working in Annapolis or the Washington suburbs, a developer may develop all of a parcel in five-acre lots or half his parcel on two-and-a-half acre lots, providing half the parcel is dedicated as open space.

The general motivation for such zoning is the notion that rural character and open space can best be maintained through the development of large-lot residential neighborhoods. However, as farm land in places like Calvert County began, in the 1980's, to be replaced by scattered, two-anda-half to five-acre-lot suburbs, it became apparent that the pattern was subsuming the rural character which had drawn people to the area in the first place. Consequently, pressures mounted for a zoning strategy which could better preserve large areas of the county's rural landscape while still accommodating growth and preserving farmers' land equities. In response, Calvert County, along with other jurisdictions, established incentives for "cluster zoning". The county's "cluster zoning" ordinance permits developers to build on smaller lots in designated "receiving areas", providing they dedicate a large portion of a development parcel to open space, and purchase "transferable development rights" (TDR's) from a farmer whose land is located in a designated "sending area". In this scenario, large areas of a county are preserved as open space through designation as "sending areas", while parcels in "receiving areas" are developed with smaller lots. This zoning also leaves a substantial portion of each developed parcel as dedicated open space.

In Calvert County, about 45,000 acres are situated in designated "sending areas", and about 17,000 in "receiving areas". ${ }^{2}$ In a "sending area", agricultural zoning is maintained with no development permitted, but for each five acres of land owned in such an area, a farmer may sell one TDR. In a "receiving area", five-acre development is permitted as described earlier, but a developer may build to a higher density through "cluster zoning", typically to a density of one-acre lots. However, the developer in such an area must purchase five TDR's for each additional lot developed beyond his matter-of-right lots, and must dedicate at least $50 \%$ of his parcel as open space.

Where such "cluster zoning" is in place, the TDR market is typically facilitated by the good offices of county planning and zoning departments. No TDR banking system is yet in place in the Middle Atlantic region. The liquidity of a farmer's equity in his land is thus tied to the development market in the "receiving areas" in his county.

These zoning strategies are illustrated in the case studies which follow. Suffice it to say, here, that even though cluster zoning represents progress toward the goal of preserving some of the region's pre-existing, traditional rural character, the

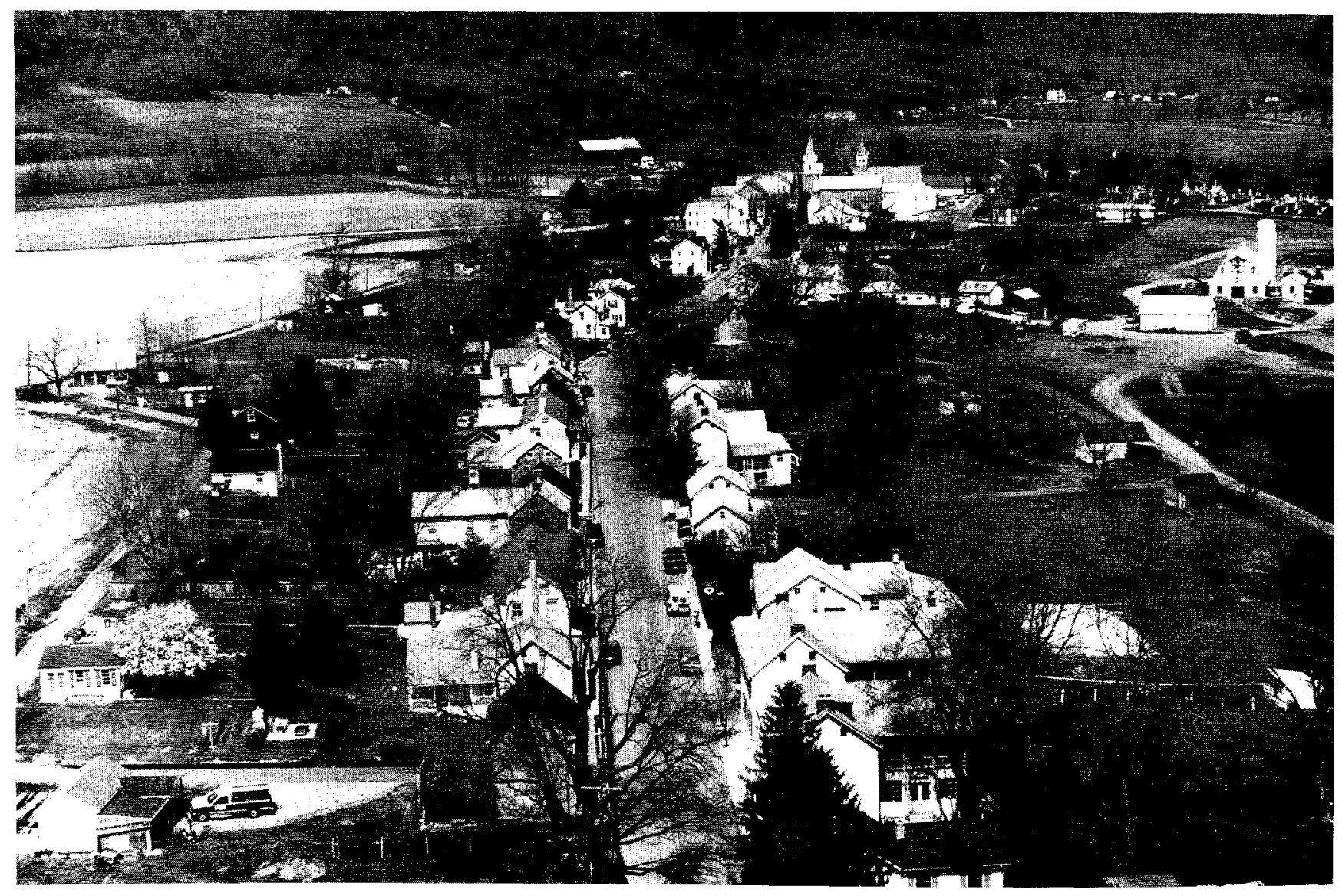

Fig. 2. Aerial view of Burkittsville, Maryland 
ultimate outcome of this strategy will be a pattern of spot developments, configured by pre-existing farm property lines. Flying over this incipient land use pattern is instructive.

\section{TRADITIONAL REGIONAL SETTLEMENT PATTERNS}

The visual image of a traditional cultural landscape looks very different from that of a large-lot development pattern. In our region, the traditional rural cultural landscape is characterized by compact, visually-identifiable villages and hamlets situated amidst working farms and natural terrain features. Figure 2, an aerial view of Burkittsville, Maryland, illustrates the character of the traditional rural cultural landscape of the Middle Atlantic region. In the earlier phases of our work, we documented the dimensional design characteristics of ten settlements like Burkittsville.

Did we discover a rigid set of urban-design dimensions or planning and aesthetic "rules of order" which governs the character of these traditional settlements? No, but it is possible to describe a common set of urban-design attributes which characterize them. Settlements are compact and identifiable. Villages are "bounded" by farm fields or natural features. They are invariably organized in linear, cross-roads or gridded plans, with variations designed to accommodate terrain or circumstance, to achieve spatial hierarchy, or to enhance a localized "sense of place". Their formal and architectural languages are coherent. Neighborhood street corridors are visually contained, "layered" by plantings, and intimate in feeling. Street blocks typically comprise these settlements' component neighborhoods, suggesting the role of their streets as social channels. Lots are often one-quarter acre or smaller in size. When they are larger, they are commonly narrow and deep, enabling even large-lot neighborhoods to define the street corridor.

In contrast to today's conventional ex-urban development patterns, these settlements accommodate a mix of uses, even at the hamlet scale. They typically include a range of housing types. Parking is accommodated in a mix of onstreet and off-street parking. Large parking lots are rare, and anomalous. Most important, these settlements, their neighborhoods and their settings convey a strong "sense of place", in contrast to the landscapes being produced by conventional large-lot development.

\section{MODELING FUTURE DEVELOPMENT ON THE TRADITIONAL RURAL PARADIGM}

Growing dissatisfaction with suburban and large-lot exurban sprawl led, in 1992, to the passage of Maryland's Economic Growth, Resource Protection and Planning Act. The Act articulates seven "visions" for the future of the state. Among other important visions, it calls for the direction of rural growth to existing population centers, and for the protection of "sensitive areas". The concept of sensitive areas has become familiar in planning circles, bringing to mind streams and their buffers, coastal zones, wetlands, floodplains, habitats of endangered species, and steep slopes. The Act, however, permits local jurisdictions to include, in their comprehensive plans, other kinds of sensitive areas deemed to be in need of protection. It also requires all local jurisdictions in the state to revise their development regulations to reflect its "visions".

The erosion of the regional cultural landscape in the Middle Atlantic region by large-lot and cluster development suggests the notion of protecting traditional cultural landscapes as another category of sensitive areas. A village zoning strategy based on regional paradigms would accomplish this objective. It would promote the development of new, compact hamlet-and-village settlements interspersed among the farms and natural features of a designated "cultural landscape sensitive area". Buffer zones of dedicated "green space" would be required. Sites would be selected to protect the overall "look" and order of the pre-existing cultural landscape, with the goal of protecting pre-existing environmental and scenic values.

In such a strategy, selected sites would be zoned for hamlet and village development on the one hand, and for farms and farm-sized residential lots on the other. In these areas, conventional developments of the one-to-five-acre variety would be ruled out. TDR's would be employed to protect farmers' equities in no-growth areas. Ideally, a TDR banking system would be put in place to make the TDR market more liquid.

\section{THE ARGUMENT FOR HAMLET AND VILLAGE ZONING}

The frame of reference in which this paper has been developed is that urban design theory is evolving in a global context of rapidly changing patterns of land use and human settlement. In developing countries, societies are experiencing nearly unmanageable population growth in and around existing urban centers, in settings of inadequate infrastructure, facilities and housing. In our own East Coast Middle Atlantic region, urbanization is more typically taking the form of sprawling growth outside of city centers, accompanied by inner city decay. Unmitigated, these trends will diminish the nation's - and the international community's ability to sustain environmental quality, and ultimately diminish the quality of life for people everywhere. While the design community in the United States has generally accepted the virtues of "new urbanist" development theory, pioneered by Andrés Duany and Elizabeth Plater-Zyberk in their neo-traditional town design work and writing, ${ }^{3}$ acceptance has been much less forthcoming in the real estate and finance communities, and consequently, in the regulatory community. In the American economic context, feasibility and market demand will ultimately determine the degree to which "new urbanist" development patterns will replace wasteful and damaging conventional development patterns. This paper presents the findings of an initial examination of the economics of the "new urbanism". 


\section{THE ECONOMICS OF CONVENTIONAL AND “NEW URBANIST" DEVELOPMENT STRATEGIES}

Seven different development strategies are compared in the following, hypothetical case studies. Five of them consist of alternative conventional and "new urbanist" land development strategies. The other two look at the economics of a village center retail building with and without residential units on upper floors.

A hypothetical waterfront site of 56.8 acres, accessed from a rural county arterial, was designed as the setting for the land-development studies. Five development strategies are considered: first, a conventional residential layout at a density of five acres per dwelling unit; second, a clustered version of the five-acre density layout; third, a "cluster zoned" project on one-acre lots, requiring the purchase of TDR's; fourth, a "new urbanist" hamlet laid out in quarter-acre lots, and last, the same hamlet laid out with "secondary streets" (upscale alleys), where an auxiliary rental ("granny") unit is permitted on each lot, behind the primary house.

An internal rate of return (IRR) analysis, utilizing a customized computer spread-sheet program, formed the basis of the economic comparisons. While it is beyond the scope of this paper to describe fully the modeling process, IRR is defined as the discount rate that causes the net present value of a stream of cash inflows and outflows to be equal to zero. In our case studies, IRR can be understood as the overall annual return on investment over a period of years in which a real estate project is developed, built, and rented or sold, assuming regular time periods for the cash inflows and outflows. Inflows consist of proceeds after expenses; outflows, of equity cash calls. The tax benefits of depreciation are included. In our studies, the IRR analysis was annualized, for simplicity, rather than being taken on a monthly periodic basis. The results are thus approximate. The land development projects are phased over four years. Year one reflects costs to initial closing of the temporary loan. In years two, three and four, equal phases of the project are assumed to be constructed and sold.

One way to compare strategies might have been to maintain a constant pricing schedule for all the land development cases, and compare profitability. Instead, we chose to target a constant rate of return for all of the alternative scenarios, and compare the pricing schedule required to produce that return. We can thus show a comparison of prices for the same house in each of the case studies. Assuming that a return of $15-20 \%$ might be expected by passive investors in a risk capital venture, a constant aftertax IRR of $30 \%$ was targeted for all of the case studies described here, reflecting an assumption that our investordeveloper is working full time in his development activity, and must be compensated for both his time and his risk. We chose a typical product for the land development cases, consisting of a 2400 sq.ft., three bedroom, two-and-a-half bath house with a "family room" and a two-car garage.

\section{Costs}

For the land-development projects, land costs and TDR costs reflect Calvert County norms. ${ }^{4}$ Construction costs are based on both Calvert County experience and on published data. ${ }^{5.6}$ Soft costs (see Figure 7) are based on experience and on interviews with various professionals. Costs are kept constant across all of the case studies, except where noted.

Similar sources were used in the determination of costs for the village center studies. Vacancy rates and operating costs were taken from published norms. Rental schedules are based on regional experience. Income tax rules for basis determination and depreciation are those which were in

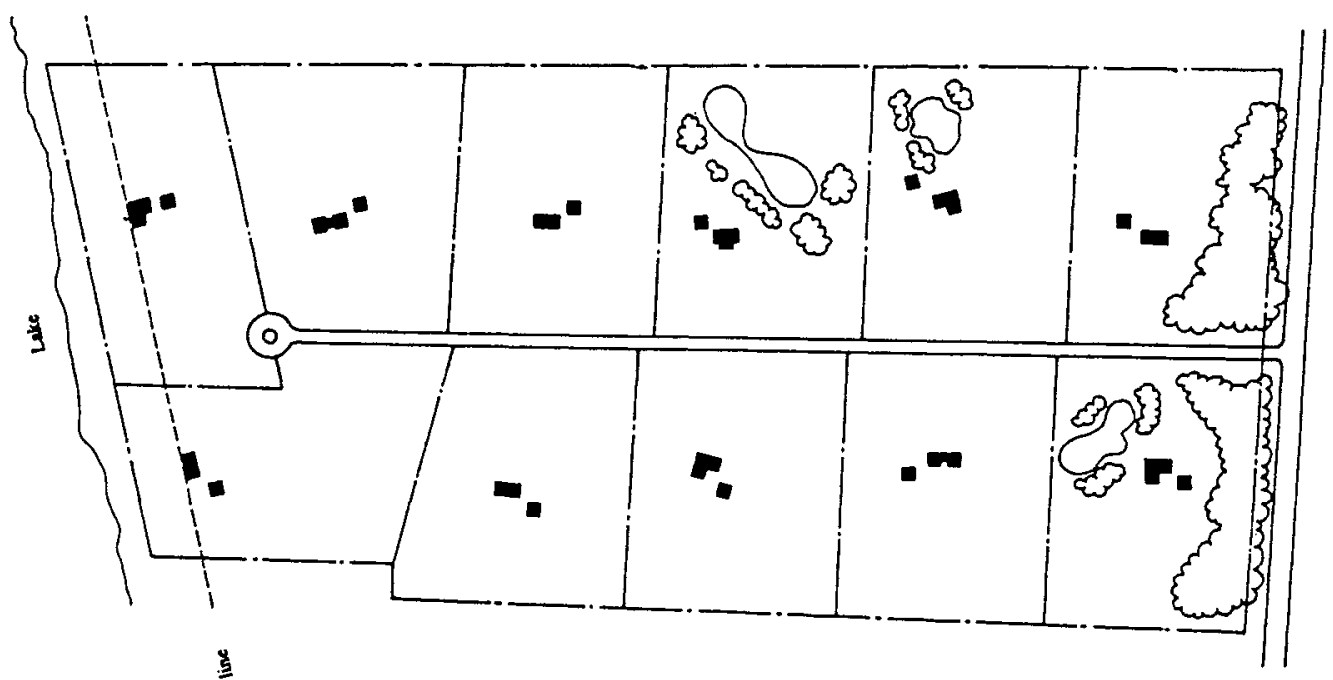

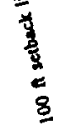

Fig. 3.

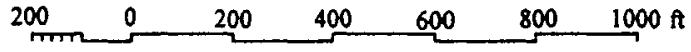

CONVENTIONAL LARGE LOT (5 a.d.u.) DEVELOPMENT 11 LOTS - 36.8 \& - NO T.D.RS REQ'D. - $100 \%$ LOT COVERAGE 
place in 1993. Since they vary so widely among jurisdictions, and in some areas are not imposed at all, off-site impact fees are not included in the costs for any of the projects. A schedule of values is included as Figure 7.

\section{CASE STUDIES:}

\section{CONVENTIONAL DEVELOPMENT STRATEGIES Conventional Five-acre Zoning}

Figure 3 illustrates a conventional development, constrained by five-acre zoning. The waterfront is assumed to be on a lake, as Maryland strictly limits what can be built within 1000 feet of a tributary of Chesapeake Bay. In this and the following two cases, houses are assumed to be on individual septic systems whose costs are included in the house construction cost, and on individual water wells. Storm water management requirements are assumed to be waived, because of the large lot size and open-section roadway design. Roads are asphalt, twenty-two feet wide, without sidewalks or street trees. The budget for road construction includes finish grading, topsoil, sodding and seeding of swales. Underground electric distribution is assumed, along with conventional street lighting. A modest budget is included for landscaping of the entrance.

To achieve the targeted after-tax IRR of $30 \%$, houses in this scheme are priced at $\$ 317,727$. In this case, the pro-rated land cost per house is $\$ 33,664$.

\section{Clustered Five-acre Zoning}

This site strategy, not illustrated here, consists of a clustered version of the project described above. Here, half of the site is left as open space, and the houses clustered on two-and-ahalf acre sites. The basic five acre density is maintained. Although the community association in this scheme would likely be able to realize some income from leasing the dedicated open space to a farmer, no consideration of this potential income is reflected in the analysis, as homeowners might prefer not to have the open space put to agricultural use. Clustering reduces site development costs. In this and the previous study, land cost is assumed to be $\$ 6500 /$ acre, an average cost based on a Calvert County normal range of $\$ 5000$ to $\$ 8000$ per acre. $^{7}$

In this scheme, a house price of $\$ 307,727$ yields the targeted IRR. The land cost per house prorates at $\$ 33,664$ per house, the same as in the previous study. Buyers in this scheme would be saving $\$ 10,000$ over those in the previous scheme, at a sacrifice of two-and-a-half acres of land.

\section{"Cluster Zoning"}

Figure 4 illustrates a conventional "cluster zoned" scheme, requiring the purchase of TDR's. Here, eleven lots may be developed as a matter of right. Our "cluster-zoning" permits lots of one acre, providing fifty per cent of the parcel is dedicated as open space. This scenario permits 26 houses to be built. In Calvert County, five TDR's must be purchased for each unit developed over the matter-of-right number. Fifteen TDR's must thus be purchased. Based on a Calvert County price range of $\$ 2300$ to $\$ 2500$ per TDR, a median value of $\$ 2400$ is used in this analysis. This cost has been folded into the raw land cost.

Here, because of the higher number of units, a community dock has been added, and priced into the development cost.

Compared to the previous schemes, our IRR target is realized with a house price of $\$ 255,058$. The aggregate land cost per house in this scenario is $\$ 21,223$. The buyer saves $\$ 62,669$ over the cost of the same house on a five-acre lot.

“NEW URBANIST" DEVELOPMENT STRATEGIES "Village Zoning" is assumed for the "New Urbanist"

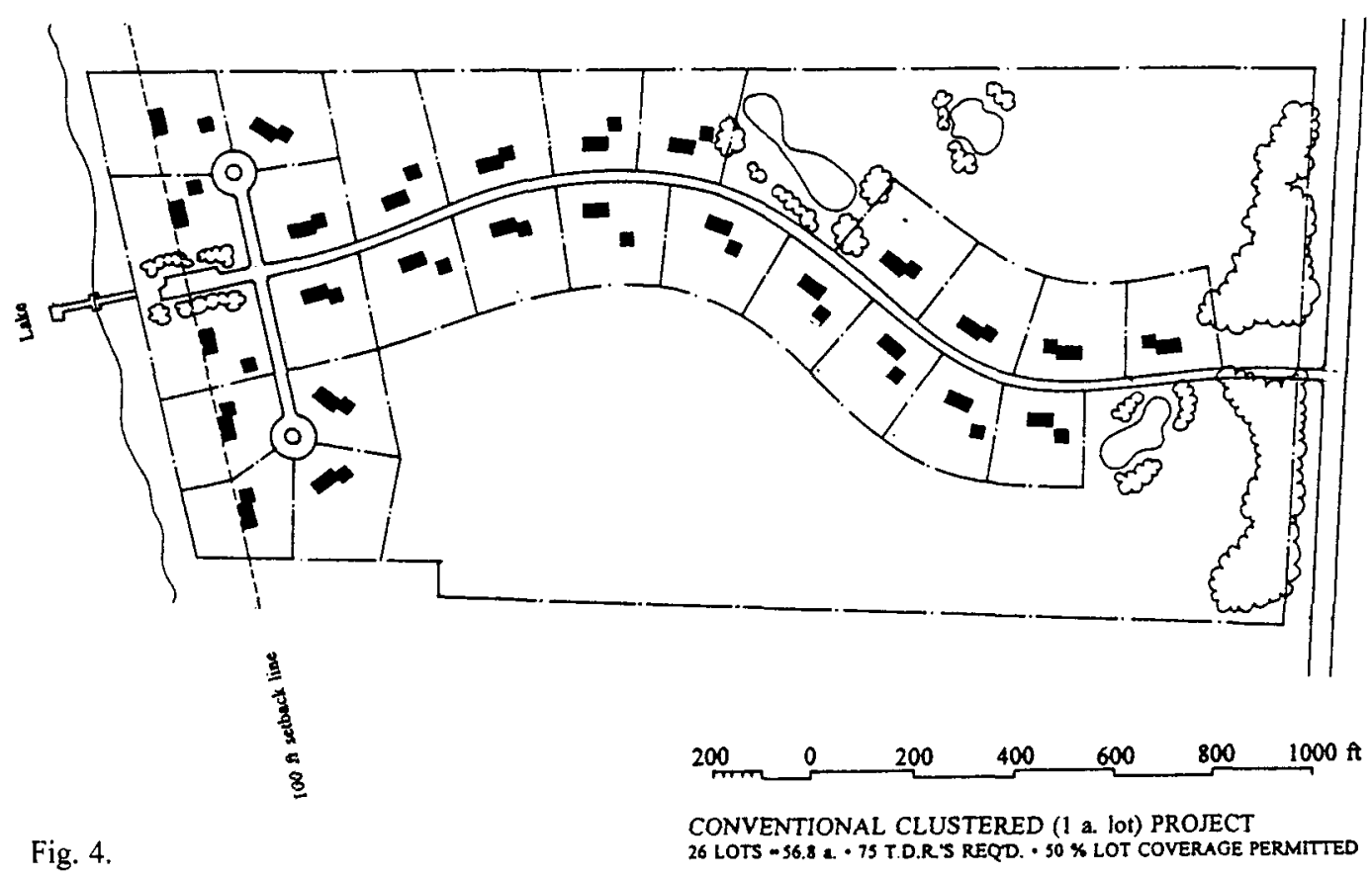


schemes described below, permitting quarter-acre lots and requiring sidewalks and tree conservation and/or street trees.

Since the 56.8 acre parcel is assumed for these schemes to be situated next to an existing town, with water and sewer available on the arterial, land cost is assumed to be slightly higher. A cost of $\$ 10,000$ per acre has thus been assumed. ${ }^{9}$ Here, the basic 22 foot roadway is kept, but its section is closed, with gutters and a granite curb. Storm water inlets are provided, but storm water management is assumed to be provided by the sewer district of the jurisdiction. A budget for street trees is included. Five-foot concrete sidewalks are included. Sewer and water and underground electrical distribution are also included, as is a budget of $\$ 21,700$ for a community dock.

Since "critical areas" constraints in Maryland are less restrictive for existing waterfront towns located on tributaries of the Bay, the two "new urbanist" developments are illustrated as being located on a river. In both, a riverfront community park is included, reflecting precedents found in other tidewater towns in the region, such as Solomon's Island and Vienna.

\section{Hamlet Development Scheme Without Alleys}

The site plan for this scheme is the same as that illustrated in Figure 5 but without the alleys. Both layouts consist of 128 units on lots averaging one quarter acre. The houses facing the community riverfront park face a public sidewalk, with their backs facing their local street, a situation which would require special care in design. The house design is kept the same as in the conventional schemes, with a two-car garage.

In this scheme, an average unit sales price of $\$ 206,600$ yields the targeted IRR. Land cost prorates at $\$ 4,538$ per unit.

\section{Hamlet Development Scheme With Alleys and Auxiliary Rental Units}

Figure 5 illustrates a variation on the previous scheme, where "secondary streets" (upscale alleys) are provided and auxiliary rental ("granny apartment") units are permitted. Here, each house is assumed to include a rental one-bedroom apartment over a two-car garage. The additional cost of the auxiliary unit is included in the house construction cost.

The notion of auxiliary rental units is an interesting one. The basic idea is that such a rental unit might provide housing for a student, a grown child, a young couple, a parent, or perhaps an "au pair". Alleys, in our culture, bring to mind a negative image. In the past, however, alleys have sometimes been elevated to the status of "secondary streets". For example, in historic Charleston, Price's Alley is composed of rear gardens, "mews" housing, and garages. Such an arrangement offers the possibility of affordable housing in an otherwise upscale community, since development costs are carried exclusively by primary units.

The added cost for the over-the-garage auxiliary rental unit in our scheme was calculated at $\$ 34,500$. Is this cost economic for the homeowner? If we assume that the unit is rented at $\$ 450$ per month, with a combined operating and vacancy rate of $30 \%$, the net income for the rental unit is $\$ 3780$ per year. Using a capitalization rate of $7.5 \%$, the "granny unit" has an economic worth of $\$ 50,400$. At a "cap rate" of $10 \%$, the granny unit's economic worth is $\$ 37,800$. The homeowner can thus expect an annual return of a little over $10 \%$ on an investment in a rental unit, or its non-cash equivalent if the unit is used to house a relative or a member of the household staff.

An average price of $\$ 241,100$ for the house and auxiliary unit yields the targeted IRR, and the land cost per unit is the same as in the previous scheme.

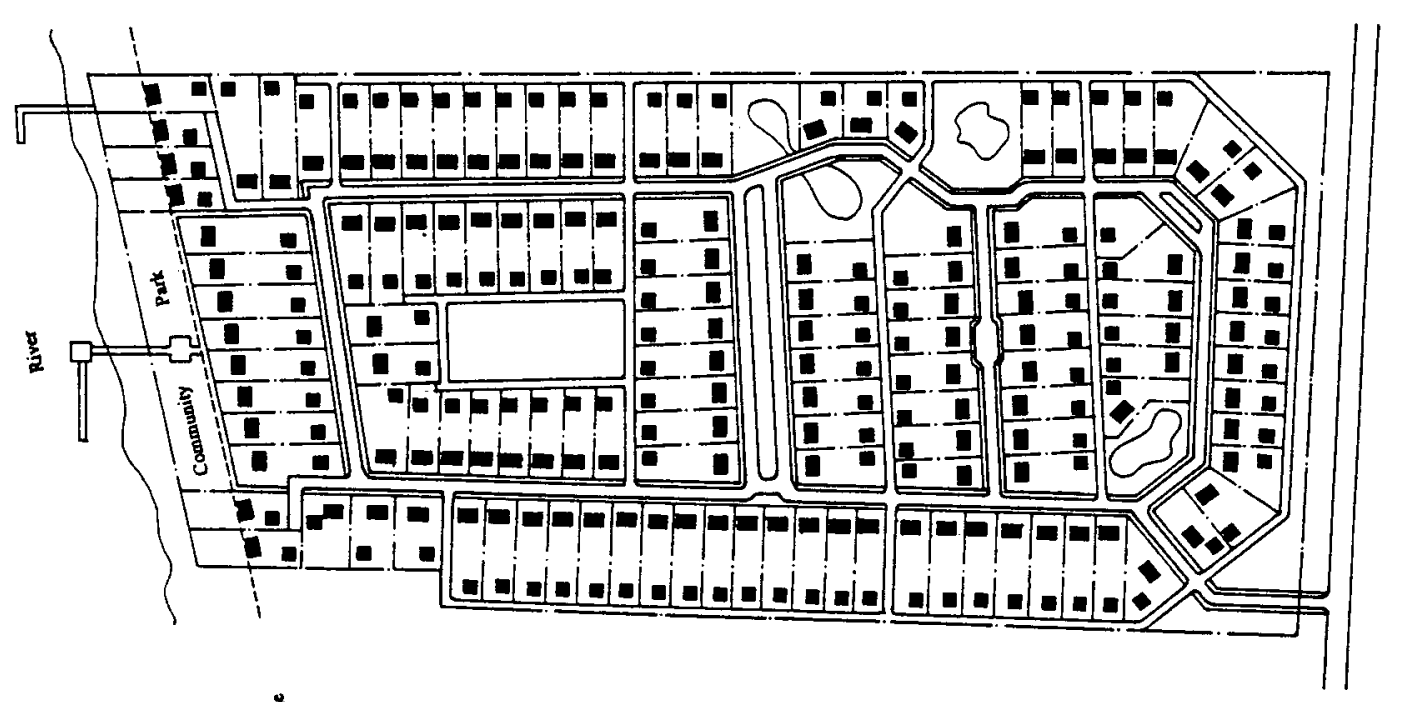

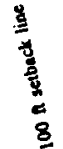

Fig. 5.

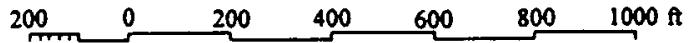

NEW URBANIST" SCHEME WTTH ALLEYS \& RENTAL UNITS 128 LOTS $-36.8 \mathrm{a} \cdot 1 / 4$ \& LOTS 

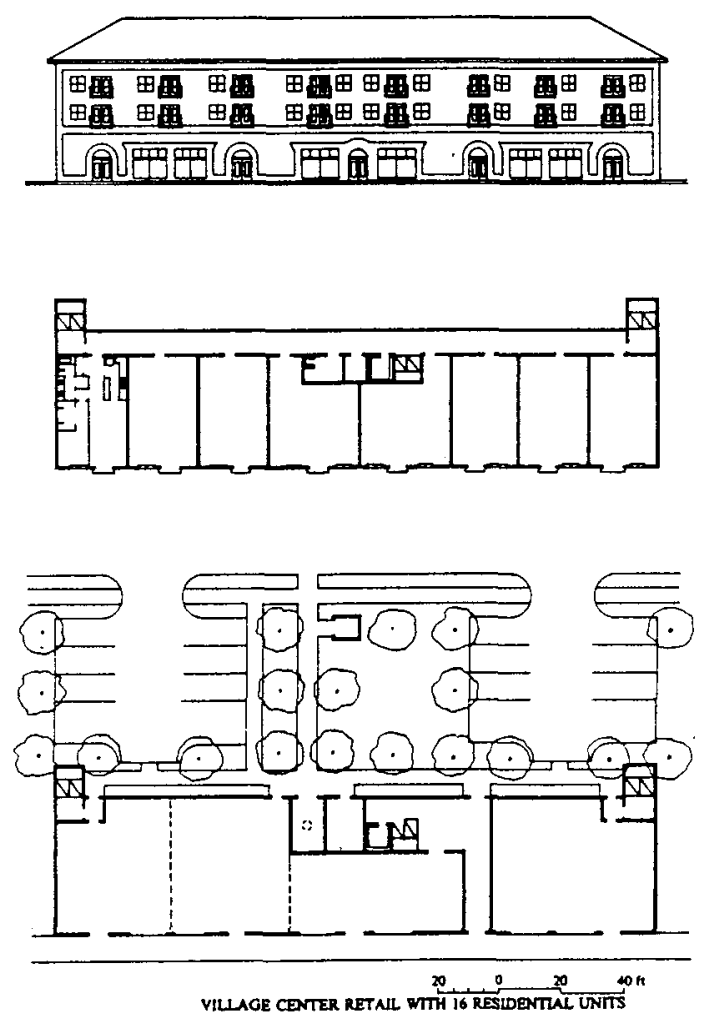

Fig. 6.

\section{VILLAGE CENTER BUILDINGS}

Two village center commercial retail buildings were studied, one with and one without residential units on upper floors. Figure 6 illustrates a building with retail space on the ground floor and sixteen one-bedroom apartments on the upper floors. The retail-only building (not illustrated) is basically the same, without the upper floors. Both occupy half-acre sites. Cost assumptions are indicated in Figure 7. Retail rental was priced at $\$ 12$ per sq. $\mathrm{ft}$. per year; residential rents were set at $\$ 575$ per month for a one-bedroom apartment. Depreciation schedules were set in accordance with IRS rules.

For these two case studies, a ten-year period was considered, as follows: first year, preliminaries; second year, to initial closing; third year, to final closing, fourth through tenth year, fully leased; end of tenth year, asset sale. In these cases, costs and rent schedules were held constant, and returns compared.

For the retail-only project, the after-tax IRR without asset sale is $27 \%$; with asset sale in the tenth year raising the yield to $37 \%$ after taxes. The mixed retail/residential building yielded somewhat less: $16 \%$ without, and $27 \%$ with asset sale. To make the mixed-use building as profitable as the retail-only building, a residential rental scale of $\$ 715$ per month would be required, a figure higher than most markets would likely bear.

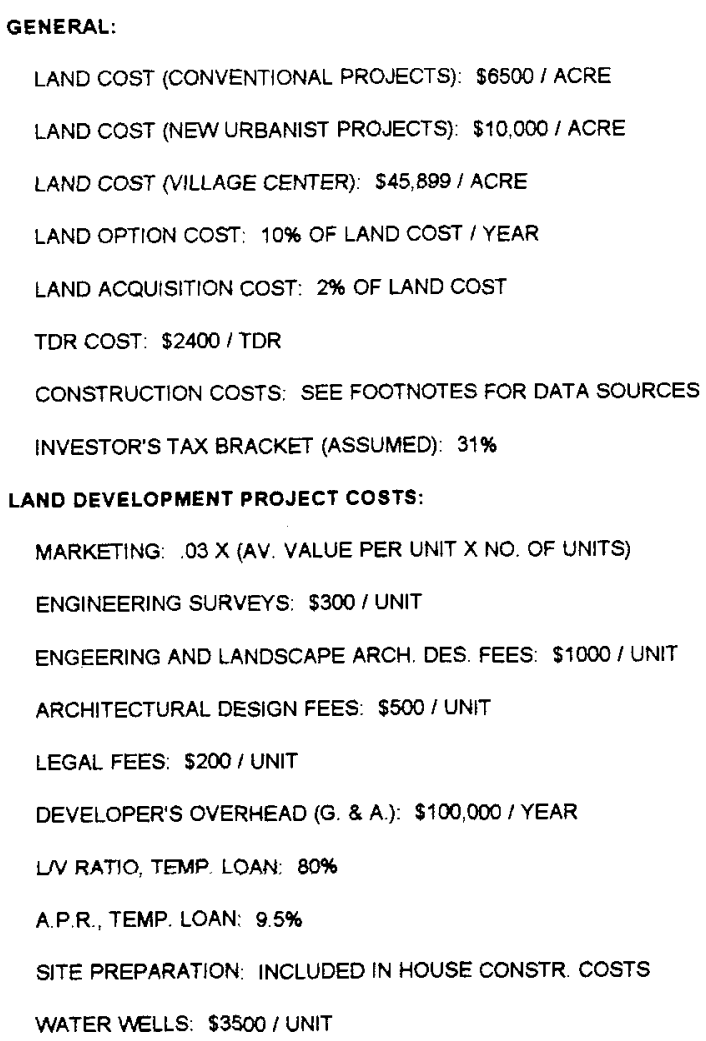

ROAD (22 FT. WDE, OPEN SECTION): $\$ 100 /$ LIN. FT.

ROAD (22 FT., CURBS, TREE STRIPS, WALKS, L'T'NG.): $\$ 172.09$ / LIN. FT

ALLEYS (18 FT. WDE, OPEN SECTION): $\$ 49.50$ / LIN. FT.

UTILITIES (ELEC. ONLY): \$38/LIN. FT

UTILITIES (WATER, SEWER, ELEC.): \$124/LIN. FT

STREET TREES (25 FT.O.C) $\$ 450$ EACH, INSTALLED

VILLAGE CENTER PROJECTS:

MARKETING: $2 \%$ OF CONSTRUCTION COST

ARCH. \& ENG'R. DESIGN FEES: $6 \%$ OF CONSTRUCTION COST

ENGINEERING SURVEYS: $0.1 \%$ OF CONSTRUCTION COST

INSURANCE: $0.4 \%$ OF CONSTRUCTION COST

INCOME: SEE TEXT

OPERATING AND VACANCY RATES: $30 \%$ OF GROSS INCOME

BASIS: ALL INDIRECT COSTS LESS OVERHEAD PLUS CONSTR. COSTS DEPRECIATION : 39 YRS. FOR RETAIL, 27.5 FOR MIXED USE BLDG.

CAPITALIZATION RATE: $10 \%$

MTGE, TERM: 20 YRS.

TEMP. LOAN A.P.R: $8.75 \%$

PERM. LOAN A.P.R.: $8 \%$

ASSUMED ASSET APPRECIATION RATE: $2 \%$ PER YEAR

Fig. 7. Table of assumed values 


\section{CONCLUSIONS}

In the land-development case studies, the "new urbanist" development strategies are shown to have the potential to be more profitable than large-lot strategies, given the assumptions made here. Conversely, the "new urbanist" strategies have significant implications for more affordable housing, especially when auxiliary rental units are permitted.

On the other hand, the mixed retail-residential village center building produced a lower return than its conventional counterpart, not surprising given today's market and costs. It appears from our study that a developer or a jurisdiction would have to provide financial incentives for mixed-use village center buildings, to make them economically competitive.

An unexamined uncertainty is the market demand and public acceptance of "new urbanist" development strategies. However, the experience of two existing neo-traditional neighborhood projects, Kentlands, near Washington, D.C., and Newpoint, near Beaufort, South Carolina, suggest that there is a significant untapped market demand for such projects.

In general, analysis suggests that the potential economic returns of "new urbanist" development strategies compare favorably with those of conventional, large-lot strategies. Based on the studies reported here, we can now argue that "new urbanist" strategies not only offer the best hope, among the available choices, of preserving the treasured, traditional cultural landscapes of rural Maryland and the Middle Atlantic region, ${ }^{10}$ but that they are economically viable.

One rural county planner summed it up this way: "All we need is one successful local project to start the trend!"

\section{NOTES}

${ }^{1}$ Hill, John W., Bruce Bozman, Larry Duket and Mike Nortrup, Modeling Future Development on the Design Characteristics of Maryland's Traditional Settlements, Pub. \# 94-05, Maryland Office of Planning with the School of Architecture, University of Maryland, 1994, 106pp, 79 illustrations

2 Interview with Greg Bowen, Deputy Director, Calvert County Office of Planning and Zoning, spring, 1995

${ }^{3}$ Duany, Andrés and Elizabeth Plater-Zyberk, Towns and Town Making Principles, Rizzoli, N.Y., 1991

${ }^{4}$ Data based on interviews with Brooke Kaine, Kaine Inc., Calvert County, Maryland, spring, 1995

${ }^{5}$ Mean's Sitework and Landscape Cost Data, 14th ed., 1995, R.S. Means Co., Inc., Kingston, MA

${ }^{6}$ Mean's Building Construction Cost Data, 51 st ed., 1993, R.S. Means Co., Inc., Kingston MA

7 Brooke Kaine interview

${ }^{8}$ Brooke Kaine interview

9 Brooke Kaine interview

${ }^{10}$ Hill, John W., A Strategy for Protecting the Historic Rural Environment, in Making Towns: Principles and Techniques, ed. by Steven W. Hurtt and Dhiru A. Thadani, School of Architecture, University of Maryland, 1994, pp. 48-51

All photographs and illustrations: John W. Hill 